\title{
Association between interleukin-18 variants and prostate cancer in Slovak population
}

\author{
J. JURECEKOVA ${ }^{1, *}$, E. BABUSIKOVA², M. KMETOVA SIVONOVA² ${ }^{2}$ H. DROBKOVA ${ }^{3,4}$, M. PETRAS ${ }^{1}$, J. KLIMENT ${ }^{3}$, E. HALASOVA ${ }^{1,4}$
}

${ }^{1}$ Comenius University in Bratislava, Jessenius Faculty of Medicine in Martin, Biomedical Center Martin, Department of Molecular Medicine, Martin, Slovakia; ${ }^{2}$ Comenius University in Bratislava, Jessenius Faculty of Medicine in Martin, Department of Medical Biochemistry, Martin, Slovakia; ${ }^{3}$ Comenius University in Bratislava, Jessenius Faculty of Medicine in Martin and University Hospital Martin, Department of Urology, Martin, Slovakia; ${ }^{4}$ Comenius University in Bratislava, Jessenius Faculty of Medicine in Martin, Department of Medical Biology, Martin, Slovakia

*Correspondence: jurecekova@jfmed.uniba.sk

Received June 1, 2016 / Accepted October 3, 2016

Interleukin-18 (IL-18), pro-inflammatory cytokine, plays important role in antitumor immunity. Polymorphisms in the IL-18 gene may lead to its altered production/activity and such modulate susceptibility to prostate cancer. The aim of this study was to evaluate the relationship between the -607 and +105 polymorphisms in the $I L-18$ gene and the risk of prostate cancer development and progression in Slovak population. The study was performed using 425 patients with prostate cancer, 270 patients with benign prostatic hyperplasia $(\mathrm{BHP})$ and 263 healthy male controls. The statistically significant association of the -607 AC genotype $(\mathrm{OR}=2.24 ; \mathrm{p}<0.001)$, CC genotype $(\mathrm{OR}=1.86 ; \mathrm{p}=0.006)$, as well as $\mathrm{C}$ allele $(\mathrm{OR}=1.27 ; \mathrm{p}=$ 0.033 ) with the higher risk of prostate cancer development was observed. No association of the $I L-18-607$ polymorphism and BHP was detected. The subset analysis revealed the significant association of the $-607 \mathrm{AC}$ genotype $(\mathrm{OR}=2.01 ; \mathrm{p}=$ 0.008 ) with development of higher-grade carcinomas (Gleason score $\geq 7$ ) and the strong association of the -607 AC genotype $(\mathrm{OR}=3.11 ; \mathrm{p}<0.001)$, CC genotype $(\mathrm{OR}=2.96 ; \mathrm{p}<0.001)$ as well as $\mathrm{C}$ allele $(\mathrm{OR}=1.51 ; \mathrm{p}=0.003)$ with the higher risk of prostate cancer development in the group of patients with PSA $<10 \mathrm{ng} / \mathrm{ml}$. The $-607 \mathrm{AC}$ genotype was also connected with significantly higher IL-18 plasma concentrations. No association between the $I L-18+105$ polymorphism and prostate cancer was observed. The analysis of the distribution of the -607 and +105 haplotypes showed significant association of the -607 $\mathrm{C} /+105 \mathrm{~A}$ and $-607 \mathrm{C} / \mathrm{+} 105 \mathrm{C}$ haplotypes with the risk of prostate cancer. This study found that the $I L-18-607$ promoter polymorphism could contribute to prostate cancer development in Slovak population. Its presence was also associated with development of higher-grade carcinomas and therefore may influences the prognosis and aggressiveness of the disease.

Key words: interleukin-18, prostate cancer, polymorphism

Prostate cancer is a heterogeneous disease exhibiting a range of clinical behaviors, from indolent, slow-growing tumors to aggressive, fast-growing tumors. Features of localized prostate cancer, such as clinical stage, prostate-specific antigen (PSA) levels and tumor grade (Gleason score) are not able to reliably distinguish aggressive form from indolent prostate cancer, especially in the intermediate risk category. Thus, better understanding of molecular and biological mechanisms responsible for prostate carcinogenesis and tumor progression is needed. Age, ethnicity, environmental and genetic factors are well-established prostate cancer risk factors. Various lines of epidemiological, pathological and molecular evidence have supported the idea that inflammation also casually contribute to prostate carcinogenesis $[1,2]$. Potential causes of prostate inflammation include hormonal perturbations such as altered androgen and estrogen levels, or infection by bacterial or viral agents, physical trauma or dietary factors [3]. Apart from these extrinsic risk factors, certain genetic factors in the inflammatory genes may contribute to increased risk of prostate cancer. Inflammation associated DNA damage, proliferation, angiogenesis, invasion and metastasis may play a role in the development and progression of prostate cancer $[4,5]$. In the present study, we focused on the role of two polymorphisms in interleukin-18 gene in prostate cancer development and aggressiveness.

Interleukin-18 (IL-18) is pro-inflammatory cytokine and belongs to the IL-1 family of cytokines. It is synthetized as an inactive intracellular precursor, which is constitutively present 
in macrophages, dendritic cells and nearly all epithelial cells. Inactive precursor requires cleavage with caspase-1 to form an active mature cytokine [6]. There are also examples where biologically active IL-18 is released without processing with caspase-1, for example in caspase-1 deficient murine macrophages after Fas ligand stimulation [7]. IL-18 participates in both innate and acquired immunity. The major functions of IL-18 include production of IFN- $\gamma$ from activated T lymphocytes and natural killer (NK) cells [8], enhancement of $\mathrm{T}$ lymphocytes and NK cells maturation and induction of pro-inflammatory cytokines and chemokines [9]. The human IL-18 gene is located on chromosome 11q22.2-q22.3 [10], and contains six exons and five introns. We decided to study two polymorphism, $-607 \mathrm{~A} / \mathrm{C}$ (rs1946518) in the promoter region and $+105 \mathrm{~A} / \mathrm{C}$ (rs549908) in exon 4 . The $\mathrm{C}$ to A change at position -607 disrupts the cAMP-responsive element-binding protein binding site [11]. The $+105 \mathrm{~A} / \mathrm{C}$ polymorphism was also found to be associated with altered IL-18 production. The AA genotype was found to be associated with significantly higher production of IL-18 than the AC genotype $[12,13]$.

\section{Patients and methods}

Study populations. The present case-control study included 425 patients with histologically verified prostate cancer, 270 patients with benign prostatic hyperplasia (BHP) and 263 healthy control subjects. Prostate cancer patients were recruited at the Department of Urology, University Hospital Martin in Slovakia, during the time period of 2005-2015. Healthy volunteers were selected from men attended routine urological examination and were confirmed to be without individual cancer history as well as any prostate disease. The study was approved by Ethics Committee of Comenius University in Bratislava, Jessenius Faculty of Medicine in Martin and both patients and volunteers gave their informed consent to participate in the study. The clinical characteristics of the subjects are summarized in Table 1.

Genotyping. Genomic DNA from subjects was isolated from whole blood using The Wizard ${ }^{\oplus}$ Genomic DNA Purification Kit (Promega) and stored at $-20{ }^{\circ} \mathrm{C}$ until genotype analysis. The IL-18 -607 polymorphism was determined using PCR reaction with sequence-specific primers. The primers sequences used for detection of IL-18 -607 polymorphism were: IL-18 -07-FC - 5'-GTTGCAGAAAGTGTAAAAATTATTAC-3' for C allele, IL-18-607-FA - 5'-GTTGCAGAAAGTGT AAAAATTATTAA-3' for A allele, IL-18-607-FK - 5' CTTTGCTATCATTCCCAGGAA- 3 ' for internal control and IL-18-607-R - 5' -TAACCTCATTCAGGACTTCC-3'. PCR reaction for each sample was performed in two reaction tubes, one containing forward primers for internal control, C allele and reverse primer. The second tube contained forward primers for internal control, A allele and reverse primer. The PCR amplification conditions were as follows: $10 \mathrm{~min}$ of initial denaturation at $95^{\circ} \mathrm{C}$, and 35 cycles consisted of $30 \mathrm{~s}$ at $95^{\circ} \mathrm{C}, 40 \mathrm{~s}$ at $56^{\circ} \mathrm{C}$ and $60 \mathrm{~s}$ at $72^{\circ} \mathrm{C}$, followed by a $10 \mathrm{~min}$ final elongation step at $72^{\circ} \mathrm{C}$.
PCR products were separated by electrophoresis on 2\% agarose gel and visualized by ethidium bromide staining. Internal control generated 301-bp fragments and $\mathrm{C}$ and $\mathrm{A}$ alleles generated 196-bp fragments. Genotypes were determined according to presence of only A allele fragments (AA), C allele fragments (CC) or both (CA). The IL-18 +105 polymorphism was determined using PCR-RFLP method. The primers sequences used for detection of IL-18 +105 polymorphism were: IL-18-105-F - 5'-TGTTTATTGTAGAAAACCTGGAATT-3', IL-18-105-R - 5'-CCTCTACAGTCAGAATCAGT-3'. The PCR amplification conditions were as follows: $5 \mathrm{~min}$ of initial denaturation at $95^{\circ} \mathrm{C}$, and 35 cycles consisted of $30 \mathrm{~s}$ at $95^{\circ} \mathrm{C}, 30 \mathrm{~s}$ at $55^{\circ} \mathrm{C}$ and $45 \mathrm{~s}$ at $72^{\circ} \mathrm{C}$, followed by a $7 \mathrm{~min}$ final elongation at $72^{\circ} \mathrm{C}$. After amplification, PCR products were digested with 2 units of TaqI restriction enzyme at $65^{\circ} \mathrm{C}$ for 2 hours. Digested products were separated by electrophoresis on 3\% agarose gel and visualized by ethidium bromide staining. The IL- $18+105$ genotypes are characterized as AA/AC/CC. The wild-type AA genotype exhibited one fragment of $148 \mathrm{bp}$. The heterozygous AC genotype resulted in 148-, 123- and 25-bp fragments, while the variant CC genotype produced fragments of 123 and $25 \mathrm{bp}$.

Plasma separation and determination of IL-18 plasma levels. Blood samples were collected to K2EDTA collection tubes to prevent clotting. Plasma samples were obtained immediately by centrifugation at $2000 \mathrm{r} / \mathrm{min}$ for $20 \mathrm{~min}$ at $4^{\circ} \mathrm{C}$, aliquoted to prevent repeated freeze and thaw cycles and stored at $-80^{\circ} \mathrm{C}$ for later use. Interleukin-18 levels were determined in 122 plasma samples of prostate cancer patients using Human IL-18 ELISA Kit (Life technologies) according to the manufacturer's protocol.

Table 1. Characteristics of prostate cancer patients, BHP patients and healthy subjects

\begin{tabular}{|c|c|c|c|}
\hline Characteristics & $\begin{array}{l}\text { Healthy controls } \\
(\mathrm{n}=263) \mathrm{n}(\%)\end{array}$ & $\begin{array}{l}\text { Prostate cancer } \\
(\mathrm{n}=425) \mathrm{n}(\%)\end{array}$ & $\begin{array}{c}\text { BHP } \\
(\mathrm{n}=270) \\
\mathrm{n}(\%)\end{array}$ \\
\hline \multicolumn{4}{|l|}{ Age (years) } \\
\hline$<50$ & 34 (12.9) & $7(1.6)$ & $19(7)$ \\
\hline $51-60$ & $132(50.2)$ & $99(23.3)$ & $70(25.9)$ \\
\hline $61-70$ & $73(27.8)$ & $178(41.9)$ & $95(36.1)$ \\
\hline$>70$ & $24(9.1)$ & $136(32)$ & $82(30.4)$ \\
\hline Mean \pm SD & $58.0 \pm 9.42$ & $66.5 \pm 7.95$ & $64.9 \pm 9.86$ \\
\hline Missing & 0 & $5(1.2)$ & $4(1.5)$ \\
\hline \multicolumn{4}{|l|}{ PSA (ng/ml) } \\
\hline $\begin{array}{l}\text { Median } \\
\text { (25th - 75th percentile) }\end{array}$ & $0.88(0.48-2.27)$ & $9.11(5.3-19.06)$ & $1.8(0.72-4.42)$ \\
\hline Missing & $82(31.2)$ & $98(23.1)$ & $81(30)$ \\
\hline \multicolumn{4}{|l|}{ Gleason score } \\
\hline$<7$ & NA & $121(28.5)$ & NA \\
\hline$\geq 7$ & NA & $182(42.8)$ & NA \\
\hline Mean \pm SD & NA & $6.93 \pm 1.25$ & NA \\
\hline Missing & NA & $122(28.7)$ & NA \\
\hline
\end{tabular}

NA - not applicable 
Table 2. Distribution of the $I L-18-607$ and +105 genotypes and alleles and their association with the risk of prostate cancer or BHP development

\begin{tabular}{|c|c|c|c|c|c|c|c|c|c|}
\hline & \multirow{2}{*}{$\begin{array}{c}\text { Healthy } \\
\text { controls }\end{array}$} & \multirow{2}{*}{$\begin{array}{c}\text { Prostate } \\
\text { cancer }\end{array}$} & \multirow{2}{*}{$\frac{\mathrm{BHP}}{\mathrm{n}}$} & \multicolumn{2}{|c|}{ Control vs. Prostate cancer } & \multicolumn{2}{|c|}{ Control vs. BHP } & \multicolumn{2}{|c|}{ BHP vs. Prostate cancer } \\
\hline & & & & OR $(95 \% \mathrm{CI})$ & $\mathrm{p}$ & OR $(95 \% \mathrm{CI})$ & $\mathrm{p}$ & OR $(95 \% \mathrm{CI})$ & $\mathrm{p}$ \\
\hline \multicolumn{10}{|l|}{$-607 \mathrm{~A} / \mathrm{C}$} \\
\hline \multicolumn{10}{|l|}{ Genotype } \\
\hline AA & 64 & 57 & 58 & 1.00 (ref.) & & 1.00 (ref.) & & 1.00 (ref.) & \\
\hline $\mathrm{AC}$ & 115 & 229 & 120 & $2.24(1.47-3.41)$ & $<0.001$ & $1.15(0.74-1.78)$ & 0.528 & $1.94(1.3-2.98)$ & 0.002 \\
\hline $\mathrm{CC}$ & 84 & 139 & 92 & $1.86(1.19-2.91)$ & 0.006 & $1.21(0.76-1.92)$ & 0.422 & $1.54(0.98-2.41)$ & 0.061 \\
\hline $\mathrm{AC}+\mathrm{CC}$ & 199 & 368 & 212 & $2.08(1.4-3.09)$ & $<0.001$ & $1.18(0.78-1.76)$ & 0.433 & $1.77(1.18-2.64)$ & 0.005 \\
\hline $\mathrm{CC}$ vs. $\mathrm{AA}+\mathrm{AC}$ & & & & $0.97(0.7-1.34)$ & 0.835 & $0.91(0.63-1.3)$ & 0.600 & $1.06(0.77-1.47)$ & 0.709 \\
\hline \multicolumn{10}{|l|}{ Allele } \\
\hline A & 243 & 343 & 236 & 1.00 (ref.) & & 1.00 (ref.) & & 1.00 (ref.) & \\
\hline $\mathrm{C}$ & 283 & 507 & 304 & $1.27(1.02-1.58)$ & 0.033 & $1.11(0.87-1.41)$ & 0.413 & $1.15(0.92-1.43)$ & 0.217 \\
\hline \multicolumn{10}{|l|}{$+105 \mathrm{~A} / \mathrm{C}$} \\
\hline \multicolumn{10}{|l|}{ Genotype } \\
\hline $\mathrm{AA}$ & 125 & 208 & 124 & 1.00 (ref.) & & 1.00 (ref.) & & 1.00 (ref.) & \\
\hline $\mathrm{AC}$ & 115 & 179 & 120 & $0.94(0.68-1.29)$ & 0.685 & $1.05(0.74-1.5)$ & 0.781 & $0.89(0.65-1.23)$ & 0.473 \\
\hline $\mathrm{CC}$ & 23 & 38 & 26 & $0.99(0.57-1.74)$ & 0.980 & $1.14(0.62-2.11)$ & 0.676 & $0.87(0.51-1.5)$ & 0.621 \\
\hline $\mathrm{AC}+\mathrm{CC}$ & 138 & 217 & 146 & $0.95(0.7-1.29)$ & 0.719 & $1.07(0.76-1.5)$ & 0.711 & $0.89(0.65-1.2)$ & 0.438 \\
\hline $\mathrm{CC}$ vs. $\mathrm{AA}+\mathrm{AC}$ & & & & $0.98(0.57-1.77)$ & 0.930 & $0.9(0.5-1.62)$ & 0.724 & $1.09(0.64-1.83)$ & 0.760 \\
\hline \multicolumn{10}{|l|}{ Allele } \\
\hline A & 365 & 595 & 368 & 1.00 (ref.) & & 1.00 (ref.) & & 1.00 (ref.) & \\
\hline $\mathrm{C}$ & 161 & 255 & 172 & $0.97(0.77-1.23)$ & 0.811 & $1.06(0.82-1.37)$ & 0.661 & $0.92(0.73-1.16)$ & 0.466 \\
\hline
\end{tabular}

Statistically significant results $(\mathrm{p}<0.05)$ are highlighted in bold

Statistical analysis. Genotype frequencies were estimated for both patients with prostate cancer and BHP and healthy controls. Both dominant and co-dominant models were evaluated. Comparison of genotype distribution and association with selected clinical data were performed with the Chi-square test and Fisher's exact test. The observed genotype frequencies of both polymorphisms were tested for Hardy-Weinberg equilibrium in control group. Haplotype analysis was performed by SHEsis program [14]. Comparison of IL-18 levels associated with different genotypes was performed by Mann-Whitney test. All $p$ values were derived from two-sided test and were considered to be statistically significant if $p<0.05$. Statistical analysis was performed using StatsDirect statistical package version 2.7.0.2.

Table 3. Haplotype frequencies of IL-18 poymorphisms in prostate cancer patients and healthy men controls

\begin{tabular}{|c|c|c|c|c|}
\hline Haplotypes & $\begin{array}{c}\text { Healthy } \\
\text { controls (\%) }\end{array}$ & $\begin{array}{c}\text { Prostate } \\
\text { cancer (\%) }\end{array}$ & $\begin{array}{c}\text { OR } \\
(95 \% \mathrm{CI})\end{array}$ & $\mathrm{p}$ \\
\hline$-607 \mathrm{~A} /+105 \mathrm{~A}$ & 27.2 & 26.6 & $0.97(0.76-1.24)$ & 0.793 \\
\hline$-607 \mathrm{~A} /+105 \mathrm{C}$ & 3.2 & 3.3 & $1.04(0.56-1.91)$ & 0.912 \\
\hline$-607 C /+105 A$ & 19 & 13.9 & $0.69(0.52-0.92)$ & 0.012 \\
\hline$-607 C /+105 C$ & 50.6 & 56.2 & $1.25(1.01-1.56)$ & 0.042 \\
\hline
\end{tabular}

Statistically significant results $(\mathrm{p}<0.05)$ are highlighted in bold

\section{Results}

We evaluated two polymorphisms in IL-18 gene, rs1946518 located in the promoter region in position -607 and rs549908 in position +105 in exon 4 . The genotype distributions in the control group were in Hardy-Weinberg equilibrium ( $p>0.05$ for both polymorphisms). Distributions of alleles and genotypes of the both polymorphisms in the group of prostate cancer patients, patients with BHP and controls are summarized in Table 2. We evaluated co-dominant, dominant as well as recessive model. Statistically significant results were in all analyses observed only in co-dominant and dominant models not in recessive model.

We observed statistically significant association of the -607 AC genotype ( $\mathrm{OR}=2.24 ; 95 \% \mathrm{CI} 1.47-3.41 ; \mathrm{p}<0.001)$, CC genotype $(\mathrm{OR}=1.86 ; 95 \% \mathrm{CI} 1.19-2.91 ; \mathrm{p}=0.006)$, as well as $\mathrm{C}$ allele $(\mathrm{OR}=1.27 ; 95 \% \mathrm{CI} 1.02-1.58 ; \mathrm{p}=0.033)$ with the higher risk of prostate cancer development. We didn't found significant association of IL-18 -607 polymorphism with the higher risk of BHP development. Patients with the -607 AC genotype have significantly increased risk of prostate cancer development also when compare to BHP $(\mathrm{OR}=1.94 ; 95 \% \mathrm{CI}$ 1.3-2.98; $\mathrm{p}=0.002)$. In case of IL-18 +105 polymorphism, we didn't detect any significant association neither in group of prostate cancer patients nor in the group of patients with $\mathrm{BPH}$. Haplotype analysis revealed significant association of $-607 \mathrm{C} /$ +105 A haplotype $(\mathrm{OR}=0.69 ; 95 \%$ CI $0.52-0.92 ; \mathrm{p}=0.012)$ 
and - $607 \mathrm{C} / \mathrm{+} 105 \mathrm{C}$ haplotype $(\mathrm{OR}=1.25$; 95\% CI 1.01-1.56; $\mathrm{p}=0.042$ ) with the risk of prostate cancer development. The results are summarized in Table 3.

To assess possible impact of the IL-18 gene polymorphisms on IL-18 levels we determined the concentration of IL-18 in plasma samples obtained from 122 prostate cancer patients. Results are summarized in Table 4. We detected that IL-18 plasma concentrations were significantly higher in group of patients with the -607 AC genotype when compare to the both -607 AA genotype $(\mathrm{p}=0.014)$ as well as -607 CC genotype $(p=0.005)$. Similar trend was detected also in case of +105 polymorphism. Patients with +105 AC genotype had significantly higher IL-18 plasma concentrations than patients with +105 AA or +105 CC genotype.

To detect possible correlations between studied IL-18 polymorphisms and selected clinical features, we strati- fied prostate cancer patients according to Gleason score (Gleason score $<7$ and Gleason score $\geq 7$ ) and PSA levels $(\mathrm{PSA}<10 \mathrm{ng} / \mathrm{ml}$ and PSA $\geq 10 \mathrm{ng} / \mathrm{ml})$. When compared to control group, the AC genotype of IL-18 -607 polymorphism was significantly associated only with development of higher-grade carcinomas (Gleason score $\geq 7)(\mathrm{OR}=2.01$; 95\% CI 1.19-3.37; $\mathrm{p}=0.008)$. We didn't observe association of any IL-18+105 polymorphism genotype with Gleason score of prostate cancer patients. Results are summarized in Table 5.

The patients group was also divided according to PSA levels. Although significant association of the IL-18 -607 AC genotype with prostate cancer risk was observed also in group of patients with PSA $\geq 10 \mathrm{ng} / \mathrm{ml}(\mathrm{OR}=1.83 ; 95 \%$ CI 1.06-3.17; $\mathrm{p}=0.029)$, much stronger association of the IL-18 -607 AC genotype (OR $=3.11 ; 95 \%$ CI 1.71-5.67; $\mathrm{p}<0.001)$, CC genotype $(\mathrm{OR}=2.96$;

Table 4. Association of IL-18 -607 and +105 genotypes with IL-18 plasma levels

\begin{tabular}{|c|c|c|c|c|c|c|}
\hline & \multicolumn{3}{|c|}{ Genotypes and IL-18 levels (pg/ml) } & \multirow{2}{*}{ AA vs. AC } & \multirow{2}{*}{ AA vs. CC } & \multirow{2}{*}{ AC vs.CC } \\
\hline & AA & $\mathrm{AC}$ & $\mathrm{CC}$ & & & \\
\hline $\begin{array}{l}\text { IL-18 -607 A/C } \\
(25 \text { th }-75 \text { th percentile) }\end{array}$ & $\begin{array}{c}153.0 \\
(122.78-212.44)\end{array}$ & $\begin{array}{c}247.97 \\
(164.6-340.34)\end{array}$ & $\begin{array}{c}185.01 \\
(109.41-257.1)\end{array}$ & $\mathrm{p}=0.014$ & $\mathrm{p}=0.672$ & $\mathrm{p}=0.005$ \\
\hline $\begin{array}{l}\text { IL-18 }+105 \mathrm{~A} / \mathrm{C} \\
(25 \text { th }-75 \text { th percentile })\end{array}$ & $\begin{array}{c}124.55 \\
(103.04-207.45)\end{array}$ & $\begin{array}{c}227.49 \\
(170.33-324.85)\end{array}$ & $\begin{array}{c}197.41 \\
(112.71-266.83)\end{array}$ & $\mathrm{p}=\mathbf{0 . 0 3 3}$ & $\mathrm{p}=0.319$ & $\mathrm{p}=\mathbf{0 . 0 4 8}$ \\
\hline
\end{tabular}

IL-18 plasma levels are given as medians with 25 th -75 th percentile range. Statistically significant results $(\mathrm{p}<0.05)$ are highlighted in bold

Table 5. Association between the $I L-18-607$ and +105 genotypes and alleles and Gleason score in prostate cancer patients

\begin{tabular}{|c|c|c|c|c|c|c|}
\hline & \multirow{2}{*}{$\frac{\text { Gleason score }<7}{\mathrm{n}}$} & \multirow{2}{*}{ OR (95\% CI) } & \multirow{2}{*}{$\mathrm{p}$} & \multirow{2}{*}{$\begin{array}{c}\text { Gleason score } \geq 7 \\
n\end{array}$} & \multirow{2}{*}{ OR $(95 \% \mathrm{CI})$} & \multirow{2}{*}{$\mathrm{p}$} \\
\hline & & & & & & \\
\hline \multicolumn{7}{|l|}{$-607 \mathrm{~A} / \mathrm{C}$} \\
\hline \multicolumn{7}{|l|}{ Genotype } \\
\hline AA & 18 & 1.00 (ref.) & & 28 & 1.00 (ref.) & \\
\hline $\mathrm{AC}$ & 58 & $1.79(0.97-3.3)$ & 0.059 & 101 & $2.01(1.19-3.37)$ & 0.008 \\
\hline $\mathrm{CC}$ & 45 & $1.91(1.01-3.6)$ & 0.049 & 53 & $1.44(0.82-2.53)$ & 0.200 \\
\hline $\mathrm{AC}+\mathrm{CC}$ & 103 & $1.84(1.04-3.27)$ & 0.036 & 154 & $1.77(1.08-2.89)$ & 0.022 \\
\hline $\mathrm{CC}$ vs. $\mathrm{AA}+\mathrm{AC}$ & & $0.79(0.51-1.24)$ & 0.312 & & $1.14(0.76-1.72)$ & 0.527 \\
\hline \multicolumn{7}{|l|}{ Allele } \\
\hline A & 94 & 1.00 (ref.) & & 157 & 1.00 (ref.) & \\
\hline $\mathrm{C}$ & 148 & $1.35(0.99-1.84)$ & 0.056 & 207 & $1.13(0.87-1.48)$ & 0.366 \\
\hline \multicolumn{7}{|l|}{$+105 \mathrm{~A} / \mathrm{C}$} \\
\hline \multicolumn{7}{|l|}{ Genotype } \\
\hline $\mathrm{AA}$ & 64 & 1.00 (ref.) & & 83 & 1.00 (ref.) & \\
\hline $\mathrm{AC}$ & 49 & $0.83(0.53-1.31)$ & 0.424 & 76 & $0.99(0.67-1.49)$ & 0.982 \\
\hline $2 \mathrm{CC}$ & 8 & $0.68(0.29-1.6)$ & 0.376 & 23 & $1.51(0.79-2.86)$ & 0.209 \\
\hline $\mathrm{AC}+\mathrm{CC}$ & 57 & $0.81(0.52-1.24)$ & 0.329 & 99 & $1.08(0.74-1.58)$ & 0.689 \\
\hline $\mathrm{CC}$ vs. $\mathrm{AA}+\mathrm{AC}$ & & $1.35(0.59-3.12)$ & 0.476 & & $0.66(0.36-1.22)$ & 0.185 \\
\hline \multicolumn{7}{|l|}{ Allele } \\
\hline A & 177 & 1.00 (ref.) & & 242 & 1.00 (ref.) & \\
\hline $\mathrm{C}$ & 65 & $0.83(0.59-1.17)$ & 0.290 & 122 & $1.14(0.86-1.52)$ & 0.360 \\
\hline
\end{tabular}

Statistically significant results $(\mathrm{p}<0.05)$ are highlighted in bold 
95\% CI 1.58-5.52; $\mathrm{p}<0.001)$ as well as $\mathrm{C}$ allele $(\mathrm{OR}=1.51 ; 95 \%$ CI 1.15-1.99; $\mathrm{p}=0.003$ ) was observed in the group of patients with PSA $<10 \mathrm{ng} / \mathrm{ml}$. We didn't observe association of any IL-18 +105 polymorphism genotype with PSA levels. Results are summarized in Table 6.

\section{Discussion}

Interleukin-18 is pro-inflammatory cytokine with dual effects on tumor development and progression. IL-18 activates NK cells cytotoxic effects and enhances Th1 immune response by stimulating the expression of IFN- $\gamma$ and TNF- $\alpha$, which results in the elimination of tumor cells in vivo [15]. On the other hand, tumor stimulating activity of IL-18 was observed under some conditions [16]. The resulting influence will depend on which effect will dominate. The exact mechanism how IL-18 contribute to prostate cancer development or progression is not well documented. Important role of this interleukin in prostate carcinogenesis is underlined by the results of the study published by Dwivedi et al. where they described that serum IL-18 levels higher than $>192.05 \mathrm{pg} / \mathrm{ml}$ are able to discriminate the noncancerous and cancerous cases with $100 \%$ sensitivity and specificity [17]. Except of the elevated levels of IL-18, observed in prostate cancer, its levels were found to gradually increase with the progression of the disease $[11,17,18]$. One explanation for increased serum levels of IL-18 in prostate cancer patients may be the production of IL- 18 by tumor cells [19], or IL-18 production induced in response to the tumor cells or other factors related to tumor development [20]. There are several single nucleotide polymorphisms in the IL-18 gene that could influence its expression or protein concentration and activity. Such effects may further lead to an alteration in an individual's immune status, consequently making carriers more or less susceptible to the disease.

We decided to study two polymorphisms in IL-18 gene, one at position +105 in exon 4 and another located in the promoter at position -607 , because their possible association with prostate cancer was not definitely confirmed or rejected. There are only five studies evaluated the effect of IL-18 -607 polymorphism on prostate cancer development and progression [21-25]. All of them were performed on Asian population and showed inconsistent results. To our knowledge, this is the first study evaluating the association of IL- $18+105$ polymorphism with prostate cancer.

Our results showed that the IL-18 -607 polymorphism (AC and CC genotypes) is significantly associated with higher risk of prostate cancer development. No association of IL-18 -607 polymorphism with the risk of BHP development was detected, which points to the fact that IL-18 -607 polymorphism can contribute preferably to development of prostate cancer. Dwivedi et al. found significant association of the AA genotype of IL-18 -607 polymorphism (OR $=0.46 ; \mathrm{p}=0.001)$ with prostate cancer and no association of this polymorphism with BHP in population of Indian men [21]. Their observations are consistent with ours, while the AA genotype of IL-18 -607 polymorphism represents

Table 6. Distribution of the $I L-18-607$ and +105 genotypes and alleles in patients stratified according to the PSA level

\begin{tabular}{|c|c|c|c|c|c|c|}
\hline & $\mathrm{PSA}<10 \mathrm{ng} / \mathrm{ml}$ & OR (95\% CI) & $\mathrm{p}$ & $\mathrm{PSA} \geq 10 \mathrm{ng} / \mathrm{ml}$ & OR (95\% CI) & $\mathrm{p}$ \\
\hline & $\mathrm{n}$ & & & $\mathrm{n}$ & & \\
\hline \multicolumn{7}{|l|}{$-607 \mathrm{~A} / \mathrm{C}$} \\
\hline \multicolumn{7}{|l|}{ Genotype } \\
\hline AA & 17 & 1.00 (ref.) & & 24 & 1.00 (ref.) & \\
\hline $\mathrm{AC}$ & 95 & $3.11(1.71-5.67)$ & $<0.001$ & 79 & $1.83(1.06-3.17)$ & 0.029 \\
\hline $\mathrm{CC}$ & 66 & $2.96(1.58-5.52)$ & $<0.001$ & 46 & $1.46(0.81-2.62)$ & 0.208 \\
\hline $\mathrm{AC}+\mathrm{CC}$ & 161 & $3.05(1.72-5.41)$ & $<0.001$ & 125 & $1.68(1.0-2.82)$ & 0.050 \\
\hline CC vs. $A A+A C$ & & $0.79(0.53-1.19)$ & 0.264 & & $1.05(0.68-1.62)$ & 0.823 \\
\hline \multicolumn{7}{|l|}{ Allele } \\
\hline A & 129 & 1.00 (ref.) & & 127 & 1.00 (ref.) & \\
\hline $\mathrm{C}$ & 227 & $1.51(1.15-1.99)$ & 0.003 & 171 & $1.16(0.87-1.54)$ & 0.321 \\
\hline \multicolumn{7}{|l|}{$+105 \mathrm{~A} / \mathrm{C}$} \\
\hline \multicolumn{7}{|l|}{ Genotype } \\
\hline AA & 93 & 1.00 (ref.) & & 71 & 1.00 (ref.) & \\
\hline $\mathrm{AC}$ & 68 & $0.79(0.53-1.19)$ & 0.263 & 67 & $1.03(0.68-1.56)$ & 0.905 \\
\hline $\mathrm{CC}$ & 17 & $0.99(0.5-1.97)$ & 0.985 & 11 & $0.84(0.39-1.83)$ & 0.664 \\
\hline $\mathrm{AC}+\mathrm{CC}$ & 85 & $0.83(0.57-1.21)$ & 0.331 & 78 & $0.99(0.67-1-49)$ & 0.981 \\
\hline CC vs. $\mathrm{AA}+\mathrm{AC}$ & & $0.91(0.47-1.75)$ & 0.773 & & $1.2(0.57-2.54)$ & 0.629 \\
\hline \multicolumn{7}{|l|}{ Allele } \\
\hline A & 254 & 1.00 (ref.) & & 209 & 1.00 (ref.) & \\
\hline $\mathrm{C}$ & 102 & $0.91(0.68-1.22)$ & 0.533 & 89 & $0.97(0.71-1.32)$ & 0.824 \\
\hline
\end{tabular}

Statistically significant results $(\mathrm{p}<0.05)$ are highlighted in bold 
protective genotype also in population of Slovak men. The same authors in another study, published in the same year, didn't observe significant association of -607 polymorphism with the higher risk of prostate cancer development in any group of prostate cancer patients divided according to different smoking habits. In all groups (tobacco chewers, smokers, combined users and non-users) they observed rather increased risk of prostate cancer development connected with the AA genotype, although results were not statistically significant [25]. Similarly, Nong et al. found no association of promoter - 607 polymorphism and a higher risk of prostate cancer in Chinese population. However, they evaluated the heterozygous AC genotype as reference [24]. The last two studies were performed on Chinese population, one hospital based [22] and another population based [23], and didn't showed significant association of IL-18 -607 polymorphism with the risk of prostate cancer development. The contradictory results from individual studies could be explained by significant differences in prostate cancer susceptibility between different populations. To our knowledge this is the first study evaluating the association of IL-18 -607 polymorphism with the prostate cancer risk in European population.

The possible mechanism how the IL-18 -607 polymorphism may contribute to higher risk of prostate cancer is that it could influence IL-18 production because of its localization at the binding site for CREB transcriptional factor [11]. To verify the hypothesis we measured the concentration of IL-18 in plasma samples of prostate cancer patients. We detected statistically significantly higher IL-18 plasma levels in patients carrying the AC genotype of IL-18 -607 polymorphism when compared to both the AA genotype as well as the CC genotype. Generally, the -607 genotypes showed AA $<$ CC $<$ AC trend in IL-18 plasma concentrations. The risk of prostate cancer development associated with -607 genotypes was increased in the same direction and therefore may correlate with higher IL-18 plasma levels. We measured the IL-18 concentration only in 122 prostate cancer patients, so our results are just preliminary and need to be confirmed in the larger group of patients. Functional impact of the -607 polymorphism was also studied by several research groups and shows inconclusive results. There are studies that didn't observe any association between -607 genotypes and IL-18 protein levels. One was performed on prostate cancer [21], others were on bladder cancer [26], HBV-related hepatocellular carcinoma [27], non-small-cell lung cancer [28] and with healthy donors [29].

On the other hand, Chen et al. observed significantly increased serum IL-18 levels in patients with lupus nephritis with the both -607 CC genotype as well as -607 AC genotype when compared to -607 AA genotype [30]. Dwivedi et al. evaluated the relative mRNA expression associated with -607 genotypes in prostate cancer patients and observed that the $\mathrm{CC}$ genotype is connected with higher mRNA expression of IL-18 than the AA genotype and the CC genotype is also connected with 5.96-fold higher mRNA expression of IL-18 in prostate cancer patients than in healthy subjects [31]. Quite opposite observation was made by Hollegaard et al., while they described significantly decreased levels of IL-18 protein in patients with spastic cerebral palsy with $-607 \mathrm{C}$ allele compared to $-607 \mathrm{~A}$ allele [13]. Interleukin-18 serum levels are complexly regulated and lot of factors influence its actual concentration. According to conflicting results from previously published studies is not possible to definitely confirm or reject the role of -607 polymorphism in regulating IL-18 protein levels. The functional impact of this polymorphism on IL-18 protein levels could be probably highly dependent on the presence of other functional polymorphisms or other conditions specific to particular disease. The exact mechanism still required clarification.

The IL-18 -607 polymorphism may influence also prognosis of the disease while our results showed that the AC genotype of IL-18 -607 polymorphism contribute preferably to development of higher-grade carcinomas (Gleason score $\geq 7$ ). Nong et al. described that the patients with the CC genotype of -607 polymorphism have significantly higher risk to develop carcinomas with Gleason score $>6$ [24].

The AC and CC genotypes of the IL-18 -607 polymorphism significantly increase risk of prostate cancer development in patients with PSA $<10 \mathrm{ng} / \mathrm{ml}$. This observation highlights the importance of IL-18 in prostate carcinogenesis and points to its possible role in different, currently not exactly known, mechanisms of prostate cancer development and progression. Verification of these results may confirm the hypothesis, that IL-18 could serve as marker of prostate cancer.

The IL-18 +105 polymorphism was not associated with prostate cancer or any clinical characteristics of the disease, despite the fact that according to previously published works, this polymorphism was also found to influence IL-18 serum concentration. We also detected significantly higher IL-18 plasma concentrations in patients with the AC genotype when compare to AA or CC genotype. Authors of the previously published studies described that the CC genotype was associated with significant decrease of IL-18 protein levels $[12,13]$. The exact mechanism how this synonymous (Ser35Ser) polymorphism may influence IL-18 protein levels is unknown, one explanation could be that it is in linkage disequilibrium with other unknown functional polymorphism. To our knowledge this is the first study evaluating possible association of this polymorphism with prostate cancer. Similar studies in different types of cancer were also unable to find the association of this polymorphism with thyroid carcinomas [32] or cervical squamous cell carcinoma [33].

The analysis of the distribution of the -607 and +105 haplotypes showed significant differences between the group of prostate cancer patients and healthy men volunteers. Haplotype CC is associated with 1.25-fold increased risk of prostate cancer development. This may reflect the fact that both alleles have to be connected with decreased IL-18 production $[11,12,13]$. On the other hand, CA haplotype might be a protective factor. The role of the $\mathrm{C}$ allele of the -607 was 
confirmed also in analysis of individual polymorphisms, but the haplotype analysis points to possible role of +105 polymorphism, which is separately not associated with increased risk of prostate cancer development, but might serve rather than promoting or suppressing factor in combination with other polymorphisms. This is the first study evaluating the effect of the -607 and +105 haplotypes in prostate cancer. Our results are preliminary, but can create the basis for further research aimed to confirmation of these results on different populations, larger sample groups.

In conclusion, this study found that IL-18 -607 promoter polymorphism may contribute to prostate cancer. The presence of the heterozygous genotype was associated with development of higher-grade carcinomas and therefore influence prognosis of the disease. The heterozygous genotype was also connected with significantly higher IL-18 plasma concentrations than other genotypes. These data might contribute to clarifying the exact mechanism underlying prostate cancer development and progression. It still need to be explored whether IL-18 polymorphisms are independent risk factors or just indirect marker of other different factors. The allelic frequencies of various polymorphisms vary across different ethnic groups, therefore our results deserve confirmation for populations with different ethnic origin.

Acknowledgements: This work was supported by the project „Biomedical Center Martin” ITMS code: 26220220187, the project is co-financed from EU sources and by the project supported by Ministry of Health of the Slovak Republic 2012/27-UKMA-4.

\section{References}

[1] HAVERKAMP J, CHARBONNEAU B, RATLIFF TL Prostate inflammation and its potential impact on prostate cancer: A current review. J Cell Biochem 2008; 103: 1344-1353. https:/ doi.org/10.1002/jcb. 21536

[2] KLEIN EA, SILVERMAN R Inflammation, infection, and prostate cancer. Curr Opin Urol 2008; 18: 315-319. https:/ doi.org/10.1097/MOU.0b013e3282f9b3b7

[3] DE MARZO AM, PALTZ EA, SUTCLIFFE S, XU J, GRONBERG $\mathrm{H}$ et al. Inflammation in prostate carcinogenesis. Nat Rev Cancer 2007; 7: 256-269. https:/doi.org/10.1038/ nrc2090

[4] COUSSENS IM, WERB Z Inflammation and cancer. Nature 2002; 420: 860-867. https:/doi.org/10.1038/nature01322

[5] NELSON WG, DEWEESE TL, DEMARZO AM The diet, prostate inflammation, and the development of prostate cancer. Cancer Metastasis Rev 2002; 21: 3-16. https:/doi. org/10.1023/A:1020110718701

[6] Dinarello CHA, Novick D, Kim S, Kaplanski G Interleukin-18 and IL-18 binding protein. Front Immunol 2013; 4: 289. https:/ doi.org/10.3389/fimmu.2013.00289

[7] TSUTSUI H, MATSUI K, OKAMURA H, NAKANISHI K Pathophysiological roles of interleukin-18 in inflammatory liver diseases. Immunol Rev 2000; 174: 192-209. https:/doi. org/10.1034/j.1600-0528.2002.017418.x
[8] OKAMURA H, TSUTSUI H, KOMATSU T, YUTSUDO M, HAKURA A et al. Cloning of a new cytokine that induces IFN-gamma production by T cells. Nature 1995; 378: 88-91. https:/doi.org/10.1038/378088a0

[9] PUREN AJ, FANTUZZI G, GU Y, SU M S, DINARELLO C A Interleukin-18 (IFNgamma-inducing factor) induces IL-8 and IL-1beta via TNFalpha production from non-CD14+ human blood mononuclear cells. J Clin Invest 1998; 101: 711-721. https:/doi.org/10.1172/JCI1379

[10] NOLAN KF, GREAVES DR, WALDMANN H The human interleukin 18 gene IL18 maps to 11q22.2-q22.3, closely linked to the DRD2 gene locus and distinct from mapped IDDM loci. Genomics 1998; 51: 161-163. https:/doi.org/10.1006/ geno.1998.5336

[11] GIEDRAITIS V, HE B, HUANG WX, HILLERT J Cloning and mutation analysis of the human IL-18 promoter: a possible role of polymorphisms in expression regulation. J Neurooimmunol 2001; 132: 2557-2576.

[12] ARIMITSU J, HIRANO T, HIGA S, KAWAI M, NAKA T et al. IL-18 gene polymorphisms affect IL-18 production capability by monocytes. Biochem Biophys Res Commun 2006; 342: 1413-1416. https:/doi.org/10.1016/j. bbrc.2006.02.096

[13] HOLLEGAARD MV, SKOGSTRAND K, THORSEN P, NORGAARD-PEDERSEN B, GROVE J Joint analysis of SNPs and proteins identifies regulatory IL18 gene variations decreasing the chance of spastic cerebral palsy. Hum Mutat 2013; 34: 143-148. https:/doi.org/10.1002/humu.22173

[14] LI Z, ZHANG Z, HE Z, TANG W, LI T et al. A partition-ligation-combination-subdivision EM algorithm for haplotype inference with multiallelic markers: update of the SHEsis (http://analysis.bio-X.cn). Cell Res 2009; 19: 519-23. https:/ doi.org/10.1038/cr.2009.33

[15] DINARELLO CA IL-18: A TH-1 inducing, proinflammatory cytokine and new member of the IL-1 family. J Allergy Clin Immunol 1999; 103: 11-24. https:/doi.org/10.1016/S00916749(99)70518-X

[16] BAI J, ZHANG Y, LIN M, ZHENG X, WANG Z et al. Interleukin-18 gene polymorphisms and haplotypes in patients with oral lichen planus: a study in an ethnic Chinese cohort. Tissue Antigens 2007; 70: 390-397. https:/doi.org/10.1111/ j.1399-0039.2007.00922.x

[17] DWIVEDI S, GOEL A, NATU SM, MANDHANI A, KHATTRI S et al. Diagnostic and prognostic significance of prostate specific antigen and serum interleukin 18 and 10 in patients with locally advanced prostate cancer: a prospective study. Asian Pac J Cancer Prev 2011; 12: 1843-1848.

[18] DWIVEDI S, GOEL A, MANDHANI A KHATTRI S, PANT KK Tobacco exposure may enhance inflammation in prostate carcinoma patients: an explorative study in North Indian population. Toxicol Int 2012; 19: 310-318. https:/doi. org/10.4103/0971-6580.103681

[19] LEBEL-BINAY S, THIOUNN N, DE PINIEUX G, VIEILLEFOND A, DEBRE B, BONNEFOY JY et al. IL-18 is produced by prostate cancer cells and secreted in response to interferons. Int J Cancer 2003; 106: 827-835. https:/doi.org/10.1002/ ijc. 11285 
[20] NONG S, ZHANG Y, ZHOU S, LI W, MA L et al. Relationship between serum IL-18 and VEGF levels in patients with prostate cancer. Chinese-German J Clin Oncol 2010; 10: 643-647. https:/doi.org/10.1007/s10330-010-0702-6

[21] DWIVEDI S, GOEL A, KHATTRI S, MANDHANI A, SHARMA P et al. Genetic variability at promoters of IL-18 (pro-) and IL-10 (anti-) inflammatory gene affects susceptibility and their circulating serum levels: An explorative study of prostate cancer patients in North Indian population. Cytokine 2015; 74: 117-122. https:/doi.org/10.1016/j.cyto.2015.04.001

[22] LIU Y, LIN N, HUANG L, XU Q, PANG G Genetic polymorphisms of the interleukin-18 gene and the risk of prostate cancer. DNA Cell Biol 2007; 26: 613-618. https:/doi. org/10.1089/dna.2007.0600

[23] LIU Y, LIU JN, WEI YZ, ZHOU Y, SONG XB et al. Effect of IL-18 gene promoter polymorphisms on prostate cancer occurrence and prognosis in Han Chinese population. Genet Mal Res 2013; 12: 820-829. https:/doi.org/10.4238/2013. March.15.2

[24] NONG S, ZHANG Y, CHENG B, HE CH, MA L et al. Effect of interleukin-18 polymorphisms -607 and -137 on clinical characteristics of prostate cancer patients. Chinese-German J Clin Oncol 2013; 12: 188-193. https:/doi.org/10.1007/s10330012-1071-0

[25] DWIVEDI S, SINGH S, GOEL A, KHATTRI S, MANDHANI A et al. Pro-(IL-18) and anti-(IL-10) inflammatory promoter genetic variants (intrinsic factors) with tobacco exposure (extrinsic factors) may influence susceptibility and severity of prostate carcinoma: a prospective study. Asian Pacific J Cancer Prev 2015; 16: 3173-3181. https:/doi.org/10.7314/ APJCP.2015.16.8.3173

[26] JAISWAL PK, SINGH V, SRIVASTAVA P, MITTAL RD. Association of IL-12, IL-18 variants and serum IL-18 with bladder cancer susceptibility in North Indian population. Gene 2013; 519: 128-134. https:/doi.org/10.1016/j.gene.2013.01.025
[27] BAO J, LU Y, DENG Y, RONG CH, LIU Y et al. Association between IL-18 polymorphisms, serum levels, and HBV-related hepatocellular carcinoma in a Chinese population: a retrospective case-control study. Cancer Cell Int 2015; 15:72. https:/ doi.org/10.1186/s12935-015-0223-Z

[28] JIA Y, ZHANG A, JIAO S, CHEN S, YAN F The interleukin18 gene promoter $-607 \mathrm{~A} / \mathrm{C}$ polymorphism contributes to non-small-cell lung cancer risk in a Chinese population. Onco Thargets Ther 2016; 9:1715-1719. https:/doi.org/10.2147/ OTT.S99581

[29] KHRIPKO OP, SENNIKOVA NS, LOPATNIKOVA JA, KHRIPKO JI, FILIPENKO ML et al. Association of single nucleotide polymorphisms in the IL-18 gene with production of IL-18 protein by mononuclear cells from healthy donors. Mediators Inflamm 2008; 2008: 309721.

[30] CHEN DY, HSIEH CW, CHEN KS, CHEN YM, LIN FJ et al. Association of interleukin-18 promoter polymorphisms with WHO pathological classes and serum IL-18 levels in Chinese patients with lupus nephritis. Lupus 2009; 18: 29-37. https:/ doi.org/10.1177/0961203308094559

[31] DWIVEDI S, GOEL A, MANDHANI A, KHATTRI S, SHARMA $P$ et al. Functional genetic variability at promoters of pro-(IL-18) and anti-(IL-10) inflammatory affects their mRNA expression and survival in prostate carcinoma patients: five year follow-up study. The Prostate 2015; 75: 1737-1746. https:/doi.org/10.1002/pros.23055

[32] CUNHA LL, TINCANI AJ, MONTALLI DA, ASSUMPCAO LV, SOARES FA et al Interleukin-10 but not interleukin-18 may be associated with the immune response against welldifferentiated thyroid cancer. Clinics 2011; 66: 1203-1208. https:/doi.org/10.1590/S1807-59322011000700014

[33] YANG YCH, CHANG TY, CHEN TCH, CHANG SCH, LIN WS et al. Genetic variants in interleukin-18 gene and risk for cervical squamous cell carcinoma. Human Immunol 2013; 74: 882-887. https:/doi.org/10.1016/j.humimm.2013.04.001 